\title{
PAULOPRIIT VOOLAINE KOGUTUD LUTSI MUINASJUTUD
}

\author{
INGE ANNOM
}

$\mathrm{P}$ aulopriit Voolaine kirjutas 1926. aastal Eesti ja Soome üliõpilaskondade hõimualbumis: „Soome sugu rahvaile on Läti eriti tähelepanu väärt maaala. Siin elas kord kurelasi, läind sajangul leidus veel vadjalaste järeltulijaid, kreevineid Bauski linna ümbruses. Praegu elavaina on tegemist liivlaste ja eestlastega. Iseäranis rohkesti on viimaseid, keda siia on siirdund ju vanust ajust pääle ja kellest paljud on jäljetult kadund. Praegusaja tähtsamaid vanemaid (200-300 a.) Eesti asundusi on Lätis, Lätgallias, Lutsi (Ludze, Ludza) linna ümbruses ja Läti Valga maakonnas Koiva (Gauja) ülijooksul Seltini ja Alamõisa (Lejasciems, Aahof) kihelkonnas" (Voolaine 1926: 83).

25-aastane Voolaine oli selleks hetkeks juba viis aastat käinud Akadeemilise Emakeele Seltsi (AES) esimese stipendiaadina kogumas Lätis Eesti keelesaarte murret. Tulihingeline Lutsi maarahva ${ }^{1}$ keele ja kultuuri hoidja ning kaitsja käis piirkonnas palju aastaid, kogudes nii palju keele- ja rahvaluuleainest, et Oskar Loorits võis kirjutada juba 1930. aastal: „P. Voolaine kogud Lutsist ja Ilzenist, mis säilitatakse Akad. Emakeele Seltsis, pakuvad ise juba palju lisamaterjali" (Loorits 1930: 170). Tähelepanuväärne on asjaolu, et Voolaine ei piirdunud ainult keelesaarte inimeste rahvaluule kogumisega, vaid tegi üleskirjutusi teistelt samas piirkonnas elavatelt rahvastelt. Nii on Lutsi maarahva pärimuse kõrval tänu Voolainele võimalik tutvuda ka latgalite, lätlaste, poolakate, venelaste, valgevenelaste, leedulaste, juutide ja mustlaste rahvaluulega.

Voolaine pärand on suur: 1963. aastal kirjutab ta, et Emakeele Seltsile on ta loovutanud ligi 6000 (5800) sedelit sõnavara (sellest 3482 sedelit Lutsist), tekstilist materjali $313 \mathrm{lk}$, päevikuid $70 \mathrm{lk}$; kirjandusmuuseumile ${ }^{2}$ ligikaudu $5000 \mathrm{lk}$ rahvaluulet ja 2000 sedelit setu rahvalaulude sõnavara; etnograafiamuuseumile $^{3}$ üle $1250 \mathrm{lk}$ etnograafilist materjali ja pildistusi, esemeid u 50 (EKLA, f 169, m 197: 1). Folkloristid on hinnanud tema materjali ka jutustajate andmete rikkuse poolest (Hiiemäe, Salve 1976: 110-113). Voolaine kogutud eri rahvaste rahvaluulet on kasutanud näiteks Loorits oma teostes: „Pharaos Heer in der Volksüberlieferung” (1935) ja „Das misshandelte und sich rächende Feuer" (1932). Eesti Kirjandusmuuseumi ja Tartu Ülikooli muinasjuttude töörühm on teinud valiku August Sanga ja Paulopriit Voolaine kogutud muinasjuttudest ja loonud veebiväljaande „Pühakud ja vägimehed. Muinasjutte Lutsi maarahvalt ja nende naabritelt” (2011). ${ }^{4}$

${ }^{1}$ Artikli autor kasutab siin ja edaspidi Lutsi keelesaare inimeste autoetnonüümi (vt Kallas 1894: 29).

${ }^{2}$ Toonane ametlik nimetus: Eesti NSV TA Fr. R. Kreutzwaldi nimeline Kirjandusmuuseum.

${ }^{3}$ Toonane ametlik nimetus: Eesti NSV Riiklik Etnograafiamuuseum.

${ }^{4} \mathrm{http}: / /$ www.folklore.ee/muinasjutt/lutsi/ (21. VIII 2015). 
Artiklis vaadeldud kogumisperiood hõlmab aastaid 1925-1937, mil Voolaine käis Ida-Läti Ludza (Lutsi) piirkonnas väga tihti ja kogus kõige rohkem rahvaluulet. ${ }^{5}$ 1920. aastatel kogus Voolaine vaid Lutsi maarahva rahvaluulet, 1930. aastatel lisaks teiste rahvaste folkloori. ${ }^{6}$ Tema kogutud Lutsi piirkonna eri rahvaste muinasjutte on Eesti Rahvaluule Arhiivis (ERA) ja AES-i kogus rohkem kui 230. Enim on üles kirjutatud imemuinasjutte (ligi 100), veel leidub rohkem kui 40 legendilist muinasjuttu, ligi 30 rumala vanapagana muinasjuttu, üle 20 novellmuinasjutu ja ligi $20^{7}$ loomamuinasjuttu. Muinasjuttude hulgas on ka mõned naljandid, mis esinevad kontaminatsioonis muinasjututüüpidega. Kõige rohkem muinasjutte on Voolaine kogunud Lutsi maarahvalt, sest keelesaared olid tema tööandjate ja tema enda peamine huviorbiit. Lisaks on ta kogunud muinasjutte ka mustlastelt, poolakatelt, nii õigeusklikelt kui ka vanausulistelt venelastelt, latgalitelt ja ühe jutu leedulaselt. Muinasjutte ei ole kirja pandud lätlastelt, kuigi ERA-s leiduvad mõned tema kirja pandud lätikeelsed rahvaluuleteated. Voolaine on märganud ja märkinud mõne maarahva esindaja assimileerumist, nt „Kazimir Molin, ${ }^{8}$ umb 30 a., lätistunud eestlane, sünd. Puudniki külas, Põlda v. (kõneleb vene keeli)" (ERA II 109, 241); „Stanislav Mekš, sünd. umb. 1965 a. Paideri külas, Põlda (Pylda, Pilda) vallas, Lutsimaal. Latgallistunud eestlane, rooma-katol. Jutustab vene keeles" (ERA II 162, 633). Märkmed jutustajate usulise kuuluvuse ja rahvuse kohta on vaid kogujapõhised, pole teada, kas Voolaine on kasutanud jutustajate enesemääratlust või otsustanud ise nende rahvusliku ja usulise kuuluvuse üle.

Erinevatel ajaloolis-poliitilistel põhjustel on Latgale olnud äärmiselt multikultuurne. Oskar Kallas oma uurimuses Lutsi maarahvast (1894) mainib, et Lutsi (Ludza), Düünaburi (Daugavpils), Räisaku (Rēzekne) maakonnas on kõige rohkem katoliku usku lätlasi - 189 000, siis luteri usku lätlasi - $28000 .^{9}$ Need olid „uuema aja sisserändajad. Neid võib tänini iserahvuseks arvata, sest Katoliiku Lätlasele on nad pea sama võorrad, kui ütleme ehk Sakslane” (Kallas 1894: 11). Oli valgevenelasi, vanausulisi venelasi, õigeusklikke venelasi. Usulise tagakiusamise eest põgenenud vanausulised olid hiljem tulnud õigeusklikega samamoodi üksteisele võõrad. Olid veel juudid, mustlased, sakslased, leedulased, poolakad, eestlased (Kallas 1984: 11). ${ }^{10}$ Kallas, kes pidas Lutsi piirkonda katoliiklikuks, arvas, et varem luteri usku olnud eestlased

${ }^{5}$ 1939. aastal jäi ta Lutsi maarahva aktiivse toetajana toonasele Läti valitsusele silma, nii et tal keelati sissesõit Lätti (vt Korjus 2010). Juba neli aastat varem kuulutati Läti territooriumil mittesoovitavaks isikuks ka liivlaste õiguste eest seisja Oskar Loorits (vt Blumberga 2004).

${ }^{6}$ Pärast Teist maailmasõda käis Voolaine Lätis veel mitmel ekspeditsioonil, kuid jutte enam nii palju ei kogunud.

${ }^{7}$ Siinjuures on huvitav märkida, et näiteks mustlastelt pole üles kirjutatud ühtegi loomamuinasjuttu. Selle liigi vähest esindatust on märganud nii Heinz Mode (1991: 31), kes on kogunud mustlasmuinasjutte üle kogu maailma, kui ka Vene mustlaste folkloori kogunud Aleksander Gessler ja Jefim Druts (1985: 26).

${ }^{8}$ Jutustajate nimekujude kirjapildis on lähtutud Voolaine kirjapanekutest.

${ }^{9}$ Kallas kasutab Vitebski kubermangu „Statistika komitee” materjale (Kallas 1894: 6).

${ }^{10}$ Eestlaste osas ilmneb siinjuures Kallase ja Voolaine andmete ja ametliku statistika faktide vahel huvitav vastuolu. Kallas kirjutas, et ainuüksi Lutsi piirkonnas asuvas Mikalova (Mihhalova, Mikaleva) vallas elas tema külastuse ajal 898 maarahva päritolu inimest, kellest umbes 40 mõistsid eesti keelt (Kallas 1894: 13, 15). Vene impeeriumi 1897. aasta rahvaloenduse andmeil elas terves Lutsi maakonnas vaid 150 isikut, kes pidasid end „tsuhnaadeks-katoliiklasteks” (vt Korjus 2010). 1925. aastal on Voolaine arvanud Põlda (Pilda) vallas elavat ligi 2000 eesti sugu inimest, kokku arvas neid Lutsi maakonnas elavat 
on seal katoliku kirikusse üle läinud. Tema arvates on ka eestlaste laulud, jutud, mõistatused, kas väljarände aegu kaasa võetud või kohapeal sündinud, katoliku usust lähtuvalt muudetud, nt „poiss paneb nõiutud tüdrukule paatre [palve] helmed kaela, loomad lähevad „patale” [pihile]” (Kallas 1894: 63). Kristi Salve leiab, et Kallas on võtnud keelejuhtidelt kuuldut liiga üksüheselt, sest järelduse tegemisel aluseks olnud mõnevärsilised vaimulike laulude fragmendid võivad olla jõudnud maarahvani hoopis hiljem väiksemate siirdlasgruppide või üksikpõgenikega (Salve 2001: 24-29). ${ }^{11}$ Voolaine kogumishetkel kuulus maarahvas valdavalt katoliku kiriku alla, mis kajastus nende maailmapildis ja selle kaudu ka folklooris. „Usk võib rahvaid ühendada ja sugulasrahvast lahutada” (Kallas 1984: 49). Seda nendib ka Voolaine. Ta kirjutab: „Ludza kreisis tähendatakse rahvuse mõistet tihti sõnadega religia, zakon" (ERA II 79, 643). Teises kohas: „Vaesel Lätgallia rahvamassil ei mängi rahvus peaaegu mingisugust rolli. Rahvuse mõiste on täiesti tume. Tihti on see usu mõistega ära vahetet. Mägize küla maamees ütles vaimustavalt: „Ma oma usku ei jäta: tšuhna $^{12}$ olin ja jään! Las lapsed ka olgu." Kirbu küla naine ütles vihastuse puhul: „Siin tsühknaid ei ole. Siin on katoliku rahvas.” Katoliku usk on lätgallasele balti lätlase võõramaks teinud kui venelase. Luterlased lätlased on sama hääd kui sakslased, mõlemad kannavad „tšiuli” nime, mis sõimunimi on. Samuti on sõna „luter” poolvandumise sõna (ah sa roojane l'uter!) L'utera usk on ńemtsa usk. Riia luterlane on ńeemets ehk säks, kes muinasjutus sarviku aset täidab" (Voolaine 1926: 85). ${ }^{13}$

Toon välja mõned põhjused, miks Lutsi maarahvas end eestlastena ei identifitseerinud:

u 5000, maakeelest arusaajaid 120. Ühemõttelistelt nimetas ta maarahvast katoliku usku olevaks (Voolaine 1925). Sama aasta Läti rahvaloenduse põhjal elas Lutsi maakonnas 12 eesti rahvusest isikut, kellest katoliiklaseks ei pidanud end keegi (Korjus 2010). 1935. aasta rahvaloenduse andmetel oli Lutsi maakonnas eesti rahvusest isikuid kokku 45, neist 22 luteriusulist, 20 katoliiklast, 3 õigeusklikku. Ajaloolase Ilmars Mežsi hinnangul oli eestlasi siiski rohkem (119), sest paljud olid end nimetanud lätlasteks, kes oskavad eesti keelt (Korjus 2010). Ka sellise arvamuse võib kahtluse alla seada, kuna näiteks 1936. aastal hindas August Sang ainuüksi maakeele oskajaiks 200 lutsilast (1936: 401). Rahvuse kohta kirjutas Voolaine: „Seda teavad väga hästi nii Põlda kui Nerza ja Mikaleva vallavalitsus, et mainitud vallus elavad eestlased, aga raamatuisse pole seda märgitud. Samuti nimetati kuskil kalendris Lutsi maakonna rahvusi, küll lätlasi, valgevenelasi, poolakaid, sakslasi, leedulasi, mustlasi ja muidugi 8000 juuti (neist 4000 Lutsi linnas 5500 elaniku peale), aga eestlastest süütsatustki” (Voolaine 1925: 374). Andmete ebaühtlus oleks huvitav uurimisteema, hetkel peegelduvad siin eri gruppide eri arusaamad rahvusest, keeleoskusest ja usust. Kui Kallas toetus väidetavalt andmete esitamisel kohalikele vallaraamatutele, siis Voolaine allikaid pole teada. N-ö ametlik statistika tugines ilmselt osaliselt rahva enesemääratlusele, mis ei pruukinud väga objektiivne olla.

${ }^{11}$ Kõige levinum on seisukoht, et eestlased siirdusid Lutsi (Ludza) piirkonda elama IdaVõrumaa aladelt XVII ja XVIII sajandil. On ka arvatud, et Lutsi keelesaarele on võrukesi ja setusid elama asunud mitmes järgus (Eesti murded IX: 13). Kristi Salve oma artiklis „Hajamõtteid keelesaartest ja nende rahvalauludest” toetab mitme rände hüpoteesi, mis selgitaks keelesaare traditsioonis mitmeid vasturääkivaid jooni (2001).

${ }^{12}$ Kallase tähelepanekute järgi nimetati niimoodi nii luteri usku lätlasi kui ka maarahvast (Kallas 1894: 30).

${ }_{13}$ Ülo Valk kirjutab, viidates Vaira Vìke-Freiberga artiklile „The Devil in Latvian Folktales: An Analysis of Character in Relation to Plot" (1982), et läti folkloorile on väga iseloomulik kuradi ilmumine saksa mõisahärrana. Sama tendents on ka eesti folklooris. Oma ja võõra vastandumine avaldub nii seisuslikult kui ka rahvuse ja usu põhjal (vt Valk 1998: 74-75). 
1) rahvuse, ja ka konkreetselt eesti rahvuse mõiste mittetundmine: „Lutsi eestlased ei tunne muidugi mitte sõna: Eestlane” (Kallas 1894: 29). „Harilikult saab maamehelt vastuseks rahvusküsimuse peale esimest korda, et nad on katoliiklased" (Voolaine 1925: 377);

2) rahvuse madal prestiiž: „Isa küsis, kas tütar ei taha end tšuhnaks kirjutada. Tütrekene nutma: ennem kelleks tahes, kuid mitte selleks, keda peetakse väljanaerdud piimanaiseks Peterburi turuplatsil" (Voolaine 1925: 377);

3) segaabielud. Kallas on pidanud keele säilimise ja puhtuse põhjuseks orjaaega - rahvas palju ringi ei liikunud. Pärast orjaaja lõppu tulnud palju segaabielusid ja keel hakanud kaduma. „Sagedasti käivad kõik kolm keelt läbisegi; tunnen mehe, kes oma 82:he aastase isaga Eesti keelt räägib, oma Läti sugust naisega Läti keelt, oma lastega, kes vene koolis käivad, kõnelevad vanemad Vene keelt: kirikus palub mees Poola keeli..." (Kallas 1894: 17-19).

\section{Jutustajad}

Muinasjuturääkijaid-informante on kokku 70. Kõige rohkem on Voolainele muinasjutte rääkinud poolatar Helena Katkēvič (26 juttu), maarahva seast Agata Jakimenko (17 juttu) ja mustlanna Felicia Beinarovič (12 juttu).

Voolaine on Jakimenko kohta kirjutanud: „Agat'ś (Agata) Jakimenko, umb. 80., eestitar, katol., kodukeel - „maakeel”, sünd. ja elab Kirbani (Škirpanos) külas, Põlda (Pilda, Pylda) vallas, Ludzi maakonnas” (ERA II 70, 569). Jutustamisoskusele lisaks väärib esiletõstmist tema ilus ja suhteliselt laenudevaba murdekeel. Voolaine sõnutsi kõneles ta oma kolme pojaga kogu pika elu vaid Lutsi murrakut (Voolaine 1978). Ka tema pojad Jeesp ja Jaan olid Voolaine informandid, kolmandalt pojalt Ludvigilt on jutte kogunud August Sang. Kokku on Voolaine kogunud jutte 25 eesti päritolu jutustajalt.

Helena Katkēviči kohta on Voolaine kirjutanud: „70 a poolatar; katoliiklane; sündinud ja elab Ludza linnas; poola keeles palub vaid jumalat, igapäevakeeleks vene keel; usub kindlasti kõike, mida kõneleb, ka muinasjutte. On villand laialt käind idapoolses Lätis, Pihkva kubermangus Velīkije Lukis; ütleb käinud olevat isegi „Moskva all”” (ERA II 61, 320). Katkēviči jutud on terviklikud, pikad, fantaasiarohked, moraliseeriva alatooniga. Väljaandesse „Pühakud ja vägimehed. Muinasjutte Lutsi maarahvalt ja nende naabritelt” on valitud seitse temalt saadud lugu. Kokku on poola jutustajaid neli.

Rahvustesse tuleb Latgale piirkonnas suhtuda siiski teatud mööndusega. Näiteks Helena Katkēviči venna Anton Kozlovskij on Voolaine määratlenud latgaliks. Pole teada, kas nii on arvanud Kozlovskij ise või Voolaine. Apolonija Grigorjevi puhul polegi Voolaine rahvust märkinud, võib-olla ehk selle pärast, et tema isa oli lätlane ja ema poolatar.

Kolmas suurjutustaja on mustlanna Felicia Beinarovič, kelle kohta on Voolaine maininud järgmist: „Jakobi t, u 65 a, snd Ludza kreisis Rundani [Rundāni] vallas. Reisinud Valgevenes ja Ukrainas, viimased 20 a elab Ludza kreisis. On mustlaste seas haruldaselt aus ja jumalakartlik, usub oma jutte. Rändab tütre Anna ja tolle tütre Olgaga Lutsimaad mööda. Rahvas kutsub Fel't́śa Jakovlevna" (ERA II 109, 49). Mustlastest jutustajaid oli 19. Kogutud materjali analüüsides selgus, et kuue aasta vältel (1931-1937) kogus Voolaine murdematerjali ühtedelt ja samadelt mustlastelt Ludza linnas ja selle lähiümbruses. 
Jutustajad olid põhiliselt pärit kolmest perekonnast: Beinarovičid, Tumaševičid, Vaidalovičid. Olemasolevatel andmetel oli tegemist kohalike läti mustlastega, kellest suurem osa rändas ringi, peamiselt küll Lutsi ja Latgale piirkonnas. Erandiks on neli Vaidaloviči perekonna liiget, kellel oli Ludzas maja, kus nad olevat ka elanud. Voolaine kirjutab, et mustlastel on Ludza linnas mitu maja (ERA II 162, 142). Tähelepanuväärne on, et suurem osa mustlastest jutustajaid olid üsna noored: kümne jutustaja ehk üle poolte vanus jääb alla 30 eluaasta, noorim oli kogumishetkel 11-aastane (Annom 2011: 6-8).

Venelastest jutustajaid on kokku 11, latgaleid 10 ja leedulasi 1.

\section{Arhiivikogud ja jutud}

Voolaine saatis rahvaluule- ja keelematerjali nii Eiseni stipendiaatide kogusse (E, StK) ${ }^{14}$ ERA-sse kui ka AES-i. Torkab silma, et Voolaine Eiseni stipendiaatide kogusse 1925. aastal saadetud muinasjutud on valdavalt lühikesed, fragmentaarsed, konspektiivsed, ümberjutustatud moega, kirjakeelsed, erandiks Piitre Fomiini „Üheksa venna õde” (Ee 451A) ja paar loomamuinasjuttu. Samal ajal on AES-i kogusse saadetud jutud terviklikumad ja murdekeelsed.

Näiteks on Voolaine ühe kogutud jutu tüübist „Hundi laulmine” (ATU 163) 1925. aastal saatnud nii AES-ile kui ka Eisenile. Mõlemad tekstid on fragmentaarsed ja üles kirjutatud samalt jutustajalt - Pätrul Bulilt.

Esimene tekst:

„Kir'elõ-kar'elõ! Kit'ś kolmõ pujaga, deeda baabaga.”

- „A to höste laul: vaja är' anda' üt'ś kitsõkõnõ.” Lät'ś tuu suzi sei ar kitsõkõzõ. Tule jälki paja ala: „Kir'elõ-kar'elõ! Deeda baabaga, kit’ś katõ pujaga. Kirelõ-karelõ, deeda baabaga, Kit'ś kolmõ pujaga."

- „Vaja är anda kitsõkõnõ.” Ańd' är kitsõkõzõ. Jäi innedest üt'ś jo suzi sei är'. Tulõ jäl'.

„Kir'elõ-kar'elõ! Deeda baabaga, kit'ś üte pujaga.” - „Vaja är anda ütekene, Ańd' ar perämädze kitsõkõzõ. Lät'ś sei är'. Tulõ jälki.

„Kir'elõ-kar'elõ! Deeda baabaga, kit’ś ütsindä. Kir'elõ-kar'elõ, deeda baabaga, kit'ś ütsindä."

AES, MT 102, 15 (2) < Lutsi (Ludza) mk, Nirza v, Tati (Ščastlivi) k P. Voolaine < Pätrul Bul (1925)

Teine tekst:

Elli deeda baabaga, kits kolmõ pujaga. Hunt tuleb akna alla ja laulab:

Kirelõ-karelõ!

Deeda baabaga,

kits kolmõ pujaga.

Mees ütleb: „A to höste laul, vaja är anda üts kitsõkõnõ!” Anva'. Läts tuu suzi, sei är kitsõkõzõ. Tulõ jälki paja ala. - Nõnda laulab hunt kõik kitsepojad ja kitse käest.

E, StK 28, 320 (8) < Lutsi (Ludza) mk, Nirza v, Tati (Ščastlivi) k - P. Voolaine < Pätrul Bul (1925)

${ }^{14}$ Tartu Ülikool deponeeris Eiseni stipendiaatide kogu Eesti Rahvaluule Arhiivi 1927. aastal. 
Köidab tähelepanu, et esimene tekst on pikem ja üleni murdeliselt kirja pandud. Teisel tekstil puuduvad vormellikud ja muinasjutule omased kinnistavad kordused, jutufragmendile on tahetud anda ilmselt mingi terviklikum vorm koos kirjakeelse alguse- ja lõpulausega. Pole teada, kas Voolaine kogus samal aastal samalt inimeselt tõesti kaks korda samasüžeelise jutu või on ta üht ja sama teksti pisut töödelnud. Ometi erinevad võrdlustekstid üksteisest ja viivad arvamusele, et Voolaine on teadlikult vahet teinud, millisesse kogusse ta missuguse materjali saadab.

Juhendamine ja nõudmised olid eri kogudes erineval tasemel. Rein Saukas märgib rahvaluulekogude mõistatusi uurinuna, et Eiseni stipendiaatide juhendamine oli tagasihoidlik või isegi puudulik: „korjanduste vormistuslik külg on äärmiselt ebaühtlane" (Saukas 2005: 91). Kui AES-i prioriteediks oli murdekeele kogumine (vt Saukas 2007: 11-19), siis Eisenil rahvaluule üldiselt. Iseenesest oli mitmele kogujale korraga sama materjali saatmine suhteliselt sagedane praktika. Näiteks Hurda algatatud rahvaluule kogumisaktsiooni ajal saadeti nii talle kui ka Eisenile sama materjal peaaegu korraga. Eisenile saadeti mustandid, Hurdale puhtandid, Eisenile saadetud materjal oli kirjakeelne, Hurdale murdekeelne (vt Saukas 2005: 12-60). Sama tendentsi võib täheldada Voolaine saadetud muinasjuttude puhul: Eisenile on saadetud valdavalt kirjakeelsed, AES-ile murdekeelsed tekstid.

Sarnane lugu on Borbul Bulli 1925. aastal jutustatud imemuinasjutuga „Pöialpoiss” (ATU 700): AES-ile saadetud 26-realine murdekeelne tekst (vt Pühakud ja vägimehed 2011, lugu nr 14) on Eiseni stipendiaatide kogusse saadetud tekstis kokku võetud üheksa kirjakeelse lausega. Novellmuinasjutt tüübist „Kuninga poeg ja sepa poeg” (ATU 920) on kogudesse jõudnud küll eri aastatel (E, StK 1925, AES 1926), ometi on esimesel juhul tegemist taas jutu kirjakeelse lühikonspektiga. Kaks Agata Jakimenkolt kogutud ja tüübilt („Rikas vend ja vaene vend”; ATU 613 „The Two Travelers” ${ }^{15}$ ) sarnast juttu on saatnud Voolaine nii AES-i kui ka ERA-sse, ometi on nende kogumisaastad erinevad (vastavalt 1926 ja 1933) ja ka jutud on mingil määral erinevad, nii et pole alust kahtlustada dubleti saatmist.

Imemuinasjutt „Rikas vend ja vaene vend” on nii Eestis kui ka Lätis hästi tuntud $^{16}$ : Eestis u 150 varianti, enamik neist Setumaalt; Ludza piirkonnast 10 (EMj I:2: 670-672; Arājs, Medne 1977: 103). Sarnaselt suurema osa Eesti variantidega on Lutsiski peategelaseks kaks venda. Rikkal vennal söögi eest endal silmad välja torgata lasknud vaene mees kuuleb tahtmatult pealt kuradite $^{17}$ juttu (kuradit on nimetatud loos eri sünonüümidega ${ }^{18}:$ kuratekij, juut $^{19}$, tigõ) ja saab juhendeid, kuidas nägijaks ja rikkaks saada. Süžee kohaselt

\footnotetext{
${ }^{15}$ Ingliskeelne tüübipealkiri on märgitud juhul, kui see erineb eestikeelsest.

${ }^{16}$ Süžee on tuntud ka Lääne-Siberisse kolinud eestlastel (vt Järv 2005: 98-123).

${ }^{17}$ Läti süžeekirjelduses kuradeid saladustejagajatena ei mainita, on vaid linnud ja loo$\operatorname{mad}($ Arājs, Medne 1977: 103).

${ }^{18}$ Samuti esineb Lutsi mustlaste juttudes mitmeid kuradi eri sünonüüme korraga (Annom 2011: 9).

${ }^{19} \mathrm{Ei}$ ole selge, kas juut on lõunaeestipärase kuradinimetuse juudas lühenenud vorm või balti päritolu (vrd lt jods 'kurat, tont', ld júodas 'must'), kuid tõenäoliselt mitte rahvuse nimetus. Valk kirjutab, et lõunaeesti juudas kannab endas varjatud vihjet mustale värvile, mis seostub värvisümboolikas kurjade jõududega (vt Valk 1998: 49). Lutsi mustlaste juttudes on kuradil tihti nimi: Ludvig, Murza, must vanamees pani Dopuuhha, lisaks muud nimetused (vt Annom 2011: 9).
} 
kuuleb vaene vend kolme õpetust. Agata Jakimenko jutustatud variantides on neid neli, küll eri järjekorras ja mõningase variatsiooniga. 1926. aasta variandis: 1) kuningatütar magab kolm aastat külje peal, hiljem selgub, et ta on pime; arstimissoovitusi ei anta; 2) silmade raviks on vaja koguda sama päeva rohule tekkinud kastet; 3) nurme peal on kirst kullaga, mille saab kätte siis, kui visata labidaga kolm korda ühele poole; 4) ilma veeta külas tuleb minna silla peale, mis on jõel, heita labidaga kolm korda ühele ja teisele poole, kuni üheksa korda saab täis.

1931. aasta variandis: 1) kuld on karbiga mäe sees; selle saab kätte, kui visata labidaga kolm korda eri poolde; 2) järgmisel hommikul tekib kaste, millega oma silmi määrides saab pime nägijaks; 3) kaks küla on veeta: vaja minna ristteele ja visata taas üheksa korda labidaga; 4) kuningatütrel on tiisikus, on vaja panna hobuseraipe pea vette ja leotada, selle veega pesta kuningatütart, ja juua seda.

Kõige suurem erinevus seisneb kuningatütre haiguse diagnoosis ja ravis. Varasemas variandis on kuningatütar haige ja pime, vaene vend ravib teda purgikesse kogutud imettegeva kaste abil, mida määrib (udu)sulega kuningatütre silmile ja näole, nii et ta saab kohe terveks. Hilisemas variandis on kuningatütrel tiisikus, vaene vend paneb tervendamiseks hobuseluud kuningatütre pesuvette ja hobuse hamba samovari sisse. Mees kastab saunas kuningatütart kolm korda järjest kolmel päeval luudeleotisega, iga kastmise ajal peab kuningatütar veel kolm korda sülitama. Lisaks on öeldud, et vaene vend pani sauna iga kord lukku.

Peab tõdema, et hobuseluudeleotis arstirohuna ületab markantsuselt Fr. R. Kreutzwaldi samatüübilises jutus „Haruldane naise truudus” kogumikus „Eesti rahva ennemuistsed jutud” väljapakutud kiriku põrandalaua alt võetud hiirepesakonna keetmise vee (Kreutzwald 1924: 126). August Annist peab seda Kreutzwaldi enda fantaasiaks (Annist 1966: 139-141). Samas on Setumaalt pärit variant, kus tuleb juua ära kiriku põrandalaua alt võetud nahkhiire pesast tehtud puljong (ERA II 174, 382/93 (4) < Setu, Mäe v, SuureRõsna k - Feodor Ilvik < Mihkel Kagõmägi (1937)). Võimalik, et jutustaja on saanud Kreutzwaldi loost innustust. Selle jututüübi variante lähemalt analüüsides selgub, et eesti rahvas on muidki kuningatütre arstimisviise välja pakkunud, näiteks konna suust võetud armulaualeiva sissesöötmine. Lisaks konna $^{20}$ enda keetmine ja keeduvee kuningatütrele sissejootmine, ka konnaverega määrimine. Veel armulaualeivast kasvanud lille keeduvesi; kuninga kolme kitse piim; maarjajäävee ja üldse vee määrimine kuningatütre haigetele silmadele, kehale; ja omapärasena - ühe tundmatu looma veri, kes käivat öösiti kuninga toas ja kes enne ei peatuvat, kui öelda: „Ooda ooda neiukene, kuni ehted kaela tuuakse"21 (ERA II 145, 105/18 (1) < Setu, Värska v, Tonja $\mathrm{k}$ - Dimofei Vabarna < Anne Vabarna (1926)). Ka on hea võtta kirikus altari eest inimeste jalgade tolmu ja nuusutada.

Vaatamata mõningatele fantaasiaküllastele arendustele koorub välja, et kuningatütart (kuningaprouat, naist) arstiti loomade liha, piima ja verega

${ }^{20}$ Konna, täpsemini kärnkonna, on peetud kristlikus maailmas juba keskajast saadik kurjuse, pahe ja patu kandjaks. Kurat võis esineda loomadest veel kassi, tuhkru, nirgi, roti, nahkhiire, hiirena jt (vt Valk 1994: 128-131).

${ }^{21}$ Selle ütluse puhul tekib võimalik seos ussisõnadega, täpsemalt ussi peatamise sõnadega: mõrsja ehi, mõrsja ehi, peig mis sinna (KKI, KS < Otepää - TPI üliõpilased (1985)). 
ning armulaualeivaga, mis on rahvausus kõik tervendavate ja jõudu andvate omadustega. Põhiliselt tervendati (kärn)konnaliha ja -verega. Võimalik, et konnale, kes on kristlikus maailmapildis üks kuradi ilmumiskujusid, on deemonlik positsioon antud ka rahvausus, ja tema tapmise järel saadakse haigusest võitu.

Rohkem ühe ja sama tüübi variante Voolaine eri kogudesse saatnud ei ole. Võimalik, et sarnaseid kirjapanekuid leidub küll rahvaluule teiste žanride võrdlusel.

\section{Jutud}

Lutsi maarahva muinasjutte on Voolaine kogunud kõige rohkem, 86. Järgnevad mustlaste omad, 55, poolakatelt 41 . Voolaine on vahet teinud vanausulistel ja õigeusklikel venelastel, vastavad arvud 38 ja 9, ainult ühe Ludza linnast pärit vene poisi puhul pole märgitud konfessiooni, temalt on kogutud kolm juttu. Latgalitelt on kogutud 30 juttu, ainult üks jutt on leedulaselt Vitániselt.

Kogusse saadetud üleskirjutusi teistelt rahvastelt on nii eesti kui ka vene keeles, venekeelseid siiski vähem - 16 juttu. Vahe üleskirjutuse ja saadetise vahel on mõnikord kuni kaks aastat. Pole teada, kas algtekst oli vene-, eestivõi muukeelne. Tõlgitud juttudes esineb aeg-ajalt vene- ja latgalikeelseid sõnu ja väljendeid, mis Voolaine sõnul on sinna jäetud teaduse huvides (ERA II 162, 168). ${ }^{22}$

Enam jutte on pärit tüüpidest „Kärbes naela asemel” (ATU 772*) ja „Viimane leht" (ATU 1184). Kummastki tüübist on seitse varianti.

Lühikest legendilist muinasjuttu „Kärbes naela asemel” on ATU andmetel katalogiseeritud vaid Eestis, Poolas, Serbias ja Kreekas. Põhjuseks võib olla jutu žanriline piiripealsus: samahästi võib see lugu olla määratud eri maades, sh ka Lätis, kas legendiks või seletusmuistendiks. Ka siinse artikli autor paigutaks tüübi pigem seletusmuistendite alla. Voolaine on seda juttu kogunud peale Lutsi piirkonna, kus see on üsna tuntud eestlaste ja latgalite seas, ka Lõuna-Eestist. Jutt räägib Jeesus Kristuse ristile naelutamisest. Raudnaelad selle jaoks olid pikad ja suured. Et vanasti oli raud kallis, varastas üks mees ühe naela ära. Kärbes istus Jeesuse rinnal ja nägi naelapea moodi välja. Ristilööja arvas, et ta on naela juba sellesse kohta löönud, ega hakanud seda otsima. Tänutäheks lubas jumal kärbsel süüa igast kausist ja igalt laualt ilma luba küsimata. Vargale aga ei pandud iga pahategu enam süüks (Loorits 1959: 161). See lühike jutt on rahvasuus muutunud aja jooksul veel lühemaks, tihti on jutust kadunud vargamotiiv. Lutsis esineb jututegelasena mustlane, kelle petmiskalduvust selle looga õigustatakse. Näiteks Jaan Jakimenko variant:

Kui sidi' lei' Krõstust risti mano, lei timäl käe' ne jala'. Sidi' tahtse' lüvvä süämest ka nakla lävi. A kärbäs istõ Krõstuzõlõ süäme pääle. Üts sidi ütel: „Nakl um jo lüüd."

(Jeesp Jakimenko vanem vend, Jaan, teie märkuse: „Tsigand ütel nii.”)

ERA II 109, 164 (7)

${ }^{22} \mathrm{Ka}$ Kallase maarahva muinasjuttude üleskirjutustes on üksikuid murdekeelseid sõnu ja väljendeid. 
Sidi tähendab Lutsi murdes juuti, tsigan (d) mustlast (Kallas 1894: 141, 142). Borbul Bull on oma jutu lõpus resümeerinud: „Selle tsigandil olõi pattu bazida, kot's miä võlss." ('Sellepärast pole mustlasel vaja pattu kahetseda, isegi kui valetab'; ERA II 162, 604 (5)).

Sama on nentinud latgalitest jutustajad Aneḷa Petrovska, Anna Kecka ja Mutjanka.

Rumala vanapagana muinasjutt „Viimane leht” on peamiselt tuntud Keskja Põhja-Euroopas. Motiivist on sugemeid juba Vanas Testamendis ning XII sajandist pärit Tristani ja Isolde loos (EM 1996: 785-788). Loost on kolm redaktsiooni: kahes neist tüssab kuradit jumal, kolmandas inimene (mees). Lutsis tuntud süžee on mehest ja kuradist. Mees laenab kuradilt raha ja ütleb, et maksab tagasi siis, kui kõik lehed on puudelt langenud. Kuna kuusk ja mänd on igihaljad, jääb kurat oma rahast ilma. Jutt on Lutsis olnud üsna maarahvakeskne, kuna seitsmest variandist kuus on jutustanud maarahvas (Jeesp Jakimenkolt kaks varianti), lisaks assimileerunud Anton Urtan ja Kazimir Molin. Üks jutt ka latgalilt Mutjankalt.

Tuntud süžee Lutsis (viis varianti) ja kogu maailmas on „Tuhkatriinu” (ATU 510A). Seda on rääkinud Lutsi maarahva seast Piitre Fomiin, Agata Jakimenko, ${ }^{23}$ omaloomingulisel moel Bronislava Bull, mustlanna Felicia Beinarovi, vanausuline venelanna Irina Timošenko ja latgal Svarackaja. Viimase variant on huvitav selle poolest, et vaenelaps saab oma ilusad (kiriku)riided kuldõuntega õunapuult, paludes end õuntega vastu üht ja teist õlga lüüa. Maarahva variandid on lähedased Setumaalt pärit vastavasisuliste juttudega. Neis muudetakse vaeslapse ema lambaks, kes hiljem tapetakse, vaeslaps matab luud maha ja edaspidi aitavad need tema ülesandeid täita. Lutsi maarahva jutud ongi huvitavad selle poolest, et mitmel neist leidub paralleele Setumaal kirjapandud juttudega. Ühine jututraditsioon võib tuleneda maarahva pärinemisest Kagu-Eesti piirkonnast. Setu jututraditsioonis omakorda esineb süžeesid, mida tuntakse veel vaid Lätis ja/või Leedus. Siin võib tegemist olla omanäolise Balti areaali jääva traditsiooniga, mille näiteid leidub ka Lutsi juttude hulgas (vt Salve 2006).

Kolm järgnevat tüüpi on esindatud nelja variandiga. Imemuinasjutu „Surm pudelis" (ATU 331) jutustajateks on olnud maarahva seast Agata Jakimenko ja ta poeg Jeesp Jakimenko, lisaks poolatar Helena Katkēvič ja mustlane Aleksander Tumaševič. Orientaalse päritoluga jutt on üsna tuntud nii Eestis kui ka Lätis, Läti muinasjutukataloog tüübi esinemist Ludza piirkonnas siiski ei näidanud. Omapärane on poolatari jutu algus, milles peategelane võtab Surma vastu kõrtsis, olles enne ukselt tagasi lükanud nii Jumala kui ka Ingli, kelle valitsusalas polevat õigust (vt Pühakud ja vägimehed 2011, nr 46). Agata Jakimenko ja Aleksander Tumaševiči loos suletakse Surm pudeli asemel tubakatoosi. Mustlase sõnul toimus see lugu 200 aastat tagasi; soldat kui peategelane kandis Surma tubakatoosis 33 aastat; kolm aastat niitis Surm inimesi. Selline ajamääratlus on pigem iseloomulik muistenditele. Lutsi mustlaste muinasjutud ongi tihti muistendliku alatooniga, millele viitavad ka juttudes sageli tegelaskujuna esinevad kurat ja rahutu surnu, tegelaste konkreetsed nimed ja lugude õnnetu lõpp (Annom 2011: 15). Ka selles loos saab Surm oma vangistaja lõpuks kätte, nagu ka Helena Katkēviči variandis.

${ }^{23}$ Üks versioon on pärit tema pojalt Ludvig Jakimenkolt, kuid selle kogujaks oli August Sang. 
Legendilist muinasjuttu „Tuule poeg sulaseks” (ATU 810A „The Devil Does Penance") on jutustanud nii vanausuline venelane Irina Timošenko kui ka õigeusklik venelane Ignat Strel'cnikov ja poolatar Helena Katkēvič. ${ }^{24}$ Selles loos kiusab kurat meest, lükates töötava mehe toidumoona peale puu või süües moona ise ära. Kuna mees on toitu õnnistanud või hoidub vandumast, peab pahandusetegija (Eestis sageli Tuule poeg) mehe juures karistuseks kolm aastat sulasena töötama. Ignat Strel'cnikovi loos esineb eluolulisi kirjeldusi: „Vanasti polnud raudteed ja Riiga sõideti hobustega. Töömees sõidab ühes peremehega Riiga linu viima" (ERA II 109, $423<$ Ludza l - P. Voolaine < Ignat Strel'cnikov (1936)).

Erinevalt on lahendatud loo lõpud, mis kisuvad naljandi poole. Strel'cnikov: „Kurat elas juba kolmanda aasta lõppu vanamehe poole ja ootas juhust, et teenistusest lahti saada. Ta magas ikka vanamehega ühes ja, kui vanamees uinus, ta tõukas rusikaga vanamehele külge. Vanamees virgus ja, kui uinus, kurat tõukas jälle külge. Viimaks vihastus vanamees ja ütles pahaselt: „Ai pojuke, mine kuradile! ( Ja ta kadus" (ERA II 109, 424). Irina Timošenko variandis on loo lõpp sarnane naljandiga „Vanaeit aitab kuradil abielupaari tülli ajada” (ATU 1353). Jumalakartlikul mehel rikastuda aidanud kurat lõpetab oma teenistuse joominguga, näidates, kuidas rikastumine ja jõudeelu mõjub hävitavalt inimese kõlbelisele palgele. Sarnase moraaliga on Helena Katkēviči jutt, mis liitub naljandiga „Joobnu arvab end paradiisis olnuvat” (ATU 1531).

Novellmuinasjuttu „Targad vastused” (ATU 921 „The King and the Fanner's Son") on jutustanud Lutsi maarahva seast Eva Jakimenko ja Tekla Jarošenko, samuti venelanna Irina Timošenko ja latgallanna Iva Kraval. Lugu põhineb küsimustel ja neile antud teravmeelsetel vastustel. Maarahva jutus leidus mõistatus: miks harak hannalda 'miks harakas on sabata'. Tõenäoliselt on see kellelgi teise suust kuuldud, sest Tekla Jarošenko viitab siin Eva Jakimenkole, kes pidi seda lugu paremini teadma. Kõige terviklikum lugu on 31-aastasel Timošenkol, ülejäänud lood on üsna fragmentaarsed.

Mittemaarahva seas on teada jututüüp „Verevennad” (ATU 303). Voolaine on variandid üles kirjutanud poolatar Helena Katkēvičilt ja mustlastelt Piiter Vaidalovičilt ning Aleksander Tumaševičilt. Üllatav, et Voolaine pole seda juttu kuulnud maarahvalt, arvestades tüübi tuntust Kallase ajal (viis üleskirjutust, vt Kallas 1900: 216-231). Katkēviči jutus on mitmeid kontaminatsioone: ATU $303+518$ („Tüli imeesemete pärast”) + 300A („Võitlus sillal”) + 519 („Tugev mõrsja"). Süžee kohaselt on vendadest tugevaim loomast sündinud vend (siin härja poeg: Byk-Volōd'a), kes seljatab ise kõik raskused, ometi loovutab ta selles loos kõrgest seisusest pruudi oma vennale Ivan Tsaaripojale, kes on temast palju nõrgem. Mustlase Tumaševiči loos on tugevaim hoopis töönaise poeg Fetmus Tubli Poiss. Omapärane on selles loos ka motiiv tüübist „Võitlus sillal”. Siin võitleb Fetmus kolme-, nelja- ja kuuepealise kuradiga. Viimasel kuradil raiub kangelane küll pead otsast, ent see kobab parema käega enda ümber, leiab maharaiutud pead ja paneb endale otsa tagasi. See stseen kordub kaks korda: „Siis sai Fetmus aru ja raius kuradil parema käe maha” (ERA II 162, 481 < Cibla v - P. Voolaine < Aleksander Tumaševič (1937)). Siin on tegemist ilmselt jutustaja fantaasiaga, kuna ka loo edasine areng on üsna ise-

${ }^{24}$ 1938. aastal on August Sang kogunud loo ka Lutsi maarahva seast pärit Meikul Jarošenkolt. 
laadne. Piiter Vaidaloviči jutt on saadetud ERA-le vene keeles. Venekeelset materjali leidub Voolaine saadetistes ka muu folkloori hulgas.

Tuntud on imemuinasjutt „Võimatud ülesanded” (ATU 465), jutustanud mustlased Aleksander Tumaševič ja Felicia Beinarovič ning poolatar Helena Katkēvič. Mustlaste variandid on sarnased AT 465C versiooniga, milles kangelane maksab kätte ülekohtustele pühakutele (vt Pühakud ja vägimehed 2011, nr 41). Redaktsioon pühakutega on tuntud ka Setumaal (vt EMj I:2: 573-574), aga mitte Lätis. Latgalitelt Zusana Dirgačovalt, Anela Petrovskalt ja poolatar Helena Katkēvičilt on üles kirjutatud legendiline muinasjutt „Vanamees põlevate söetükkidega" (ATU 751B*) (vt Pühakud ja vägimehed 2011, nr 52), mis on kogu Lätis tuntud jututüüp, kuid Eestis kogutud peamiselt Setumaalt.

\section{Kokkuvõte}

Käesolevas artiklis olen vaadelnud muinasjutte, mida Paulopriit Voolaine kogus aastatel 1925-1937 Lätimaalt Ludza (Lutsi) linna ümbrusest. Akadeemilise Emakeele Seltsi esimese stipendiaadina huvitus ta algul Lutsi piirkonnas asuvate eestlaste murdest, hiljem ka nende rahvaluulest, saates materjali Eiseni stipendiaatide ja Eesti Rahvaluule Arhiivi kogusse. Eri kogudesse saadetud materjal on tekstiliselt erinev. 1930. aastatel hakkas ta koguma folkloori teistelt Lutsi piirkonnas elavatelt rahvastelt: latgalitelt, poolakatelt, venelastelt jne. Kuna Läti Latgale regioon on ajaloolistel ja poliitilistel põhjustel olnud multikultuurne, siis on eri rahvad üksteisega kõrvuti elades mõjutanud üksteise maailmapilti ja (rahva)kultuuri, sealhulgas ka rahvajutte. Selles mõttes on Voolaine kogutud materjal hea analüüsiaines eri rahvaste ja sellest tulenevalt ka eri religioonide ja rahvaluule võrdlemiseks. Oskar Kallas, kes esimesena uuris Lutsi maarahva rahvaluulet, leidis sellest mõjutusi sel ajal piirkonnas domineerinud katoliku usust. Usuline kuuluvus oli ka veel Voolaine kogumise ajal olulisem kui rahvus. Ka muinasjuttudes leidub religioonile vihjavaid elemente.

Muinasjutte rääkis Voolainele kokku 70 jutustajat. Kõige rohkem on neid talle kõnelenud poolatar Helena Katkēvič, maarahva seast Agata Jakimenko ja mustlanna Felicia Beinarovič.

Voolaine saadetud Lutsi piirkonna eri rahvaste muinasjutte on arhiivikogudes üle 230. Koguseliselt on kõige rohkem imemuinasjutte, kuid kõige populaarsemad tüübid olid „Kärbes naela asemel” (ATU 772*) ja „Viimane leht” (ATU 1184), millest esimene kuulub legendiliste muinasjuttude ja teine rumala vanapagana muinasjuttude hulka. Kummastki tüübist oli seitse varianti. Imemuinasjuttudest olid teistest populaarsemad „Tuhkatriinu” (ATU 510A) ja „Surm pudelis” (ATU 331). Veel oli hästi tuntud legendiline muinasjutt „Tuule poeg sulaseks” (ATU 810A) ja novellmuinasjutt „Targad vastused” (ATU 921). Mittemaarahva seas olid tuntud veel imemuinasjutud „Verevennad” (ATU 303) ja „Võimatud ülesanded” (ATU 465) ning legendiline muinasjutt „Vanamees põlevate söetükkidega" (ATU 751B*). Mõningal juhul on juttude puhul märgata teatud tüübiredaktsioonide järjepidevust ühe või teise rahvuse piires. Näiteks muinasjutus „Tuhkatriinu” (ATU 510A) on maarahva variandid lähedased Setumaalt kogutud variantidele, erinedes teiste rahvaste variantidest. Ühine jututraditsioon võib viidata vähemalt ühe osa Lutsi maarahva 
pärinemisele Setumaa piirkonnast. Mustlaste juttudes on märgata teatavat omapärast muistendlikkust, mis eristab nende jutte teistest. Ühiseks võib eri rahvuste puhul pidada kuradi nimetamist juttudes ohtra sünonüümivaramuga. Ühes jutus võib leiduda vähemalt kolm sünonüümi, kuigi nimetused ei pruugi eri rahvustel kattuda.

Selles artiklis on välja toodud vaid mõni aspekt Lutsi piirkonna rikkalikust muinasjutuvaramust. Võrdlevat uurimist pakub Paulopriit Voolaine kogutud mahukas materjal kindlasti edaspidigi asjahuvilistele.

Artikli valmimist on toetanud Haridus- ja Teadusministeeriumi projekt EKKM 14-342 „Eesti muinasjuttude teaduslikud väljaanded”.

\section{Käsikirjalised allikad}

Eesti Rahvaluule Arhiivi kogud: AES, MT; E, StK; ERA; KKI, KS.

V o o l a i n e, Paulopriit 1963. Paulopriit Voolaine tegevus eesti keele alal. EKLA, f 169, m 197: 1-3.

\section{Kirjandus}

An n ist, August 1966. Friedrich Reinhold Kreutzwaldi muinasjuttude algupära ja kunstiline laad. Tallinn: Eesti Raamat.

A n n o m, Inge 2011. Lutsi mustlaste juttudest. - Pro Folkloristica XVI. Kuldkalake. Toim Ave Tupits, Kanni Labi. Tartu: Eesti Kirjandusmuuseumi Teaduskirjastus, lk 5-17.

A r āj s, Kārlis, M e d n e, Alma 1977. Latviešu pasaku tipu rādītājs. Rīga: Zinātne. AT = Antti Aarne, Stith Thompson 1961. The Types of the Folktale. A Classification and Bibliography. (FF Communications 184.) 2nd rev. Helsinki: Suomalainen Tiedeakatemia.

ATU = Hans-Jörg Uther 2004. The Types of International Folktales. A Classification and Bibliography. Based on the System of Antti Aarne and Stith Thompson. Part I: Animal Tales, Tales of Magic, Religious Tales, and Realistic Tales, with an Introduction. (FF Communications 284.) Part II: Tales of the Stupid Ogre, Anecdotes and Jokes, and Formula Tales. (FF Communications 285.) Part III: Appendices. (FF Communications 286.) Helsinki: Suomalainen Tiedeakatemia.

B l u m b e r g a, Renāte 2004. Oskar Loorits ja liivlased. - Mäetagused, nr 24. Hüperajakiri. Tartu, lk 9-17. http://haldjas.folklore.ee/tagused/nr24/blumberga.pdf

Eesti murded IX = Mari Mets, Anu Haak, Triin Iva, Grete Juhkason, Mervi Kalmus, Miina Norvik, Karl Pajusalu, Pire Teras, Tuuli Tuisk, Lembit Vaba, Eesti murded IX 2014. Lõunaeesti keelesaarte tekstid. Tallinn: Eesti Keele Instituut, Tartu Ülikool.

EM 1996 = Enzyklopädie des Märchens: Handwörterbuch zur historischen und vergleichenden Erzählforschung. Kd 8. Berlin-New York: de Gruyter.

EMj I:2 = Eesti muinasjutud I:2. Imemuinasjutud. (Monumenta Estoniae Antiquae V.) Koost ja toim Risto Järv, Mairi Kaasik, Kärri Toomeos-Orglaan, Inge Annom. Tartu: Eesti Kirjandusmuuseumi Teaduskirjastus, 2014. 
Gessler, Druts 1985 = Алексей Гесслер, Ефим Друц. Сказки и песни рожденные в дороге: Цыганский фольклор. Москва: Главная редакция восточной литературы изд-ва „Наука”.

H i i e m ä e, Mall, S a lv e, Kristi 1976. Olgu õnne, et elada, olgu tervist teha tööda... - Rahvapärimuste koguja 10. Tartu, lk 110-113.

Järv, Risto 2005. Eesti imemuinasjuttude tekstid ja tekstuur. Arhiivikeskne vaatlus. Doktoritöö. (Dissertationes folkloristicae Universitatis Tartuensis 7.) Tartu: Tartu Ülikooli Kirjastus.

K a 11 a s, Oskar 1894. Lutsi maarahvas. Helsingi: Soome Kirjanduse Seltsi trk.

Kallas, Oskar 1900. Kaheksakümmend Lutsi Maarahva muinasjuttu. Jurjev: Schnakenburg.

Korjus, Hannes 2010. Rahvaloendused ja Lutsi maarahvas. - Kirjalik ettekanne muinasjutuseminaril „Lutsi muinasjutud - 110 aastat hiljem”. Ludza.

Kre utzw ald, Friedrich Reinhold 1924. Eesti rahva ennemuistsed jutud. Tallinn: Tallinna Eesti Kirjastus-Ühisus.

L o o r i ts, Oskar 1930. Mõningad läti laensõnad eestis. - Eesti Keel 1929, kd 8, lk 168-189.

L o o r it s, Oskar 1959. Estnische Volkserzählungen. Berlin: Walter de Gruyter \& Co.

M o d e, Heinz 1991. Zigeunermärchen aus aller Welt. Frankfurt am Main: Insel.

Pühakud ja vägimehed 2011 = Pühakud ja vägimehed. Muinasjutte Lutsi maarahvalt ja nende naabritelt. Koost ja toim Inge Annom, Risto Järv, Mairi Kaasik, Kärri Toomeos-Orglaan. Tartu. http://www.folklore.ee/muinasjutt/lutsi/index. html

S a lve, Kristi 2001. Hajamõtteid keelesaartest ja nende rahvalauludest. - Regilaul - keel, muusika, poeetika. Toim Tiiu Jaago, Mari Sarv. Tartu: Eesti Kirjandusmuuseum. Eesti Rahvaluule Arhiiv, lk 17-55.

S a lve, Kristi 2006. Etnilise ajaloo kajastusi Eesti muinasjuturepertuaaris (Läänemere - Balti suhted). - Võim \& kultuur 2. Koost Mare Kõiva. Tartu: Eesti Kirjandusmuuseum, Eesti Kultuuriloo ja Folkloristika Keskus, lk 327-329.

S a n g, August 1936. Lutsi maarahvas a. 1936. - Eesti Kirjandus, nr 9, lk 399-409.

S a u k a s, Rein 2005. Eesti mõistatuste allikalugu II. (Reetor 6.) Toim Arvo Krikmann. Tartu: Eesti Kirjandusmuuseum, Eesti Kultuuriloo ja Folkloristika Keskus.

S a u k a s, Rein 2007. Eesti mõistatuste allikalugu III. (Reetor 7.) Toim Arvo Krikmann. Tartu: Eesti Kirjandusmuuseum, Eesti Kultuuriloo ja Folkloristika Keskus.

V a lk, Ülo 1994. Kurat Euroopa usundiloos. Sissejuhatus demonoloogiasse. Tallinn: Vikerkaar.

V a 1 k, Ülo 1998. Allilma isand: kuradi ilmumiskujud eesti rahvausus. Tartu: Eesti Rahva Muuseum.

V o o l a i n e, Paulopriit 1925. Lutsi maarahvas 1925. a. - Eesti Kirjandus, nr 9, lk 372-379.

V o o l a i n e, Paulopriit 1926. Lutsi ja Koiva maarahvas. - Eesti ja Soome üliõpilaskondade hõimualbum I. Tartu: Postimees, lk 83-88.

V o o l a i n e, Paulopriit 1978. Lutsi rahvalaulik Agata Jakimenko. - Tartu Riiklik Ülikool 3. III, nr 6, lk 2 . 


\section{The Ludza fairy tales collected by Paulopriit Voolaine}

Keywords: Paulopriit Voolaine, Ludza enclave, Estonian and comparative folkloristics, fairy tale

The article analyses the fairy tales collected from the environs of Ludza town, Latvia, in 1925-1937 by Paulopriit Voolaine. The collected material was sent by him to the Academic Mother Tongue Society, to M. J. Eisen's Scholarship Fellows collection and to the Estonian Folklore Archives. In the 1920s his interest was focused on the Estonian narrative tradition of the Ludza enclave, but in the 1930s he also collected the folklore of other peoples inhabiting the region. As, for historical and political reasons, the Latgale region of Latvia has been rather multicultural Voolaine's material is excellent for cross-ethnic comparative analysis. The number of the fairy tales collected by Voolaine from different peoples of the Ludza region exceeds 230. Most of them can be classified as miracle fairy tales, but the most popular types of tales are „Fly in Place of Nail” (ATU 772*) and „The Last Leaf” (ATU 1184), the former of which is a legend-like fairy tale and the latter belongs to tales about a gullible Devil. Some versions tend to occur more consistently with certain peoples. The Ludza Estonian versions of „Cinderella” (ATU 510A), for example, resemble those collected from Setumaa rather than those told among the neighbouring peoples. The fairy tales told by Gypsies, however, share some features with legends.

The article addresses but a few aspects of the treasury of fairy tales from the Ludza region. The voluminous material collected by Voolaine certainly remains a valuable source for anybody interested in comparative folklore studies.

Inge Annom (b. 1973), MA, Estonian Literary Museum, Estonian Folklore Archives, Assistant,inge@folklore.ee 